\title{
THE IMPLEMENTATION OF INDONESIAN NATIONAL QUALIFICATION FRAMEWORK CURRICULUM IN HIGHER EDUCATION INSTITUTION
}

\author{
Primastuty IImia Hidayatul Insani ${ }^{*}$, Noor Irwan, Mindarti Lely Indah \\ Master of Arts in Higher Education Program, Faculty of Administrative Science, \\ University of Brawijaya, Indonesia \\ *E-mail: miainsani1992@gmail.com
}

\begin{abstract}
Curriculum is a design of learning activities to develop the quality of learning in order to achieve educational goals, in this case especially at higher education. The curriculum that has been established by the Ministry of Research, Technology, and Higher Education of the Republic of Indonesia is the one based on the Indonesian National Qualification Framework (INQF). The curriculum should be applied by all universities in Indonesia both state and private universities. In this case, Public Administration Study Program in the Faculty of Administrative Science, University of Brawijaya, has implemented this curriculum since 2014 both to obey the regulation established by the government and to produce qualified alumni.
\end{abstract}

\section{KEY WORDS}

Curriculum, INQF, public administration, framework, education.

As with the issuance of Presidential Regulation Number 8 of 2012 on Indonesian National Qualification Framework and the Regulation of the Minister of Education and Culture of the Republic of Indonesia Number 73 of 2013 on the Implementation of the Indonesian National Qualification Framework for Higher Education, all the existing study programs in universities throughout Indonesia have to comply with the regulations. The purpose of the regulations is to produce qualified alumni as to prepare competent candidates in their fields in accordance with IQNF standards. In order to meet these requirements, in 2014 the Public Administration Study Program, Faculty of Administrative Sciences, University of Brawijaya has started to implement the policies as required by the central government.

The steps taken by the Public Administration Study Program in complying with the policy declared by the central government are (1) goal setting, (2) curriculum formulating process, (3) curriculum implementation, and (4) assessment on the effectiveness of curriculum implementation. Of the four stages, almost all have strong support from the communication, resource, disposition, and bureaucratic structures as described by Edward III (1980), except in the stages of implementation that lacks the support of disposition in the form of commitment from colleagues, seen from the incomplete Lesson Plans and the inconsistency of lecturers in writing Lecturing Journals. This makes the implementation of the curriculum not optimal.

\section{THEORETICAL REVIEW}

The Indonesian National Qualification Framework (IQNF). Based on the Act Number 20 of 2003 on the National Education System in Chapter I (Wahyudin, 2014), curriculum is defined as, "a set of plans and regulations about the aims, content, and material of lessons and the method employed as the guidelines for the implementation of learning activities to achieve given education objectives." Curriculum of higher education based on the Act Number 12 of 2012 Article 35 Paragraph 1 is, "a set of plans and regulations about the aims, content, and material of lessons and the method employed as the guidelines for the implementation of learning activities to achieve Higher Education objectives."

Curriculum based on the Indonesian Qualification Framework (IQNF) is "a stand-alone system and a bridge between education and training sectors to create qualified person and certified person through formal and non-formal education, as well as training and work 
experience." In this case, qualified graduates can be proven by certificates obtained from formal education in the form of diplomas and from non-formal education (courses for obtaining IELTS, TOEFL, TOEIC and other certificates). Certificates on competency prove certified graduates. These certificates are given after completing a competency test organized by the Training Providers and the Competency Test Institutions of the Professional Certification Agency under the auspices of the National Agency for Professional Certification.

Theory of Public Policy Implementation Model. Based on "the Handbook of Public Policy Analysis Theory, Politics and Methods" (2007), public policy implementation is divided into 3 models, i.e. top-down theories, bottom-up theories, and hybrid theories. The top-down implementation model is the implementation of a policy whose activities can only be done after the decision is made and formalized by the central government, while the bottom-up is a model of public policy implementation that starts from the 'bottom' by identifying the network of actors in policy submission. In other words, the implementer of the policy (organization under the central government) is given certain authority in implementing and developing the activities in accordance with regulations made by the central government in which the implementer of the policy will be obliged to account for the results of its activities to the central government. The hybrid public policy implementation model is a combination of topdown and bottom-up policy implementation models.

Factors that Support the Implementation of Public Policy. Four factors influence the success of public policy implementation based on Edward III (1980, in Suwarno, 2017). First is communication, i.e. the information is clear enough and detail from the policy maker so that the policy actors can understand the policy goals and objectives. Second is resource, i.e. adequate resources such as facilities, staff (human resources), authority, information, and adequate finance. Third is disposition, i.e. the existence of strong attitudes and commitments by policy actors such as being responsible, honest, consistent, and able to work together so the purpose of policy implementation can be realized. Fourth is the bureaucracy structure, i.e. the of Operational Procedure used as a guide in implementing the policy and the support of bureaucracy organization

\section{METHODS OF RESEARCH}

The research is descriptive qualitative method, and the data analysis technique refers to Yin (2011, pp. 178-179) consisting of: (1) compile database, (2) disassemble database, (3) reassemble database, (4) interpret data, and (5) conclude.

The focus of the study is on the implementation of IQNF Curriculum in the Public Administration Study Program at the level of Sarjana; this covers (a) the legal basis, (b) the purpose, (c) the policy actors, (d) the mechanism, (e) the curriculum structure and, (f) learning outcomes (LO). The next focus of the study is on factors that inhibit and support the implementation of IQNF Curriculum.

The study was done at the Faculty of Administrative Sciences, University of Brawijaya, Malang, Indonesia. The type of data used in this study is primary data and secondary data (Given, 2008). Three techniques of data collection, observation, interview and documentation, were employed.

\section{RESULTS AND DISCUSSION}

The findings and discussion cover the legal basis for the policy, the purpose of policy implementation, the policy actors, the mechanism of curriculum implementation, the structure of the curriculum, Learning Outcome, as well as supporting and inhibiting factors in the implementation of IQNF curriculum.

The Legal Basis for QNF Curriculum. Here are the legal bases that regulate the implementation of IQNF Curriculum at the Public Administration Study Program:

- Presidential Regulation Number 8 of 2012 on Indonesia National Qualification Framework; 
- Regulation of the Minister of Education and Culture of the Republic of Indonesia Number 73 of 2013 on the Implementation of the Indonesian National Qualification Framework for Higher Education; and

- Regulation of the Minister of Research, Technology, and Higher Education of the Republic of Indonesia Number 44 of 2015 on National Standards of Higher Education

The three regulations are the bases of the implementation of IQNF Curriculum by the central government mandated to the University of Brawijaya. This is written in the Decree of the Rector in the form of guidebooks. Furthermore, the Decree is mandated to the Faculty of Administrative Sciences, written in the form of the Decree of the Dean of Faculty of Administration Number 210 of 2014. Thus, it can be said that the implementation of IQNF Curriculum policy at the Public Administration Study Program follows the top-down model, as expressed in the "Handbook of Public Policy Analysis Theory, Politics, and Methods" (2007). Mazmanian \& Sabatier in Smith \& Larimer (2009) state the implementation of a policy could be done by the institution at the lowest level (in this case the Faculty of Public Administration) when there are official regulations made by top-level institutions (in this case the central government).

The Purpose of QNF Curriculum. Implementation of IQNF-based curriculum in the Public Administration Study Program has two kinds of objectives, i.e. to produce qualified human resources and certified graduates as stipulated in the regulations. Thus, the graduates are expected to be able to develop their knowledge and have high level of competitiveness in the world of work.

As for the reality in the field, Public Administration Study Program of the undergraduate level only focuses on how to produce qualified graduates. This is because the graduates only get a diploma and Diploma Supplement. The graduates cannot yet have a certificate of competency test as the National Agency for Professional Certification has not established the Professional Certification Agency on Public Administration.

The Actors of IQNF Curriculum. The actors who play a role in the policy implementation are actually all academic civitas in UB such as the Rector, Deans (Dean and Vice Dean I), study programs, departments, professors, lecturers, staff, and students. However, the most important actors in the implementation of IQNF Curriculum in Public Administration Program of the undergraduate level is the Study Program, the Department and the Vice Dean I. Thus, it can be said that the Rector assigns the Dean and the Dean assigns the Vice Dean I who then coordinates with the Department.

Furthermore, the Department coordinates intensively with the Study Program to prepare everything needed in implementing the curriculum policy. The Department must prepare the required budget and the lecturers as the resource. Then the Study Program team forms a team to formulate the policy implementation through intensive discussion to prepare a draft of curriculum that will be implemented. This form of coordination is one of the key issues in the implementation of the policy, i.e. 'communication' as stated by Edward III (1980, in Nugroho, 2008, pp. 447) that "communication concerns on how the policy is communicated to the organization and/or public, availability of resources to implement the policies, attitudes and responses of the parties involved, as well as how the organizational structure of the policy actors."

The pattern of implementation in the Administration Study Program is the top-down model. As expressed in the "Handbook of Public Policy Analysis Theory, Politics, and Methods" (2007) states that the implementation of top-down policy starts from the highest level of organization (macro-implementation level) to the lowest level of the organization (micro-implementation level). As seen from the autonomy of the lecturers in the preparing Lesson Plans, the content, method, and others, it can be said that the Public Administration Study Program uses bottom-up model. According to Berman (1978, in Liedl, 2011) that in the implementation of bottom up policy, micro-implementation level responds to the policy provided by macro-implementation level (the Vice Dean I) by developing the program (preparing the Lesson Plans). Both models are used simultaneously by the Public Administration Study Program level in implementing the IQNF curriculum policy, and thus it can be concluded that the policy implementation model uses the hybrid implementation 
model, a combination of top-down implementation model and bottom-up implementation model.

The Mechanism of IQNF Curriculum. The mechanism of implementation of IQNF Curriculum policy can be seen based on the compilation of IQNF Curriculum which refers to the regulations. It uses a hybrid model, i.e. a policy implementation model that combines the regulations set by the central government and the various aspirations that arise from below which in this case is the Public Administration Study Program. The Public Administration Study Program has implemented in accordance with the regulations made by macro-implementation level such as the Ministry of Research, Technology, and Higher Education of the Republic of Indonesia, the university, and the faculty. Furthermore, the Study Program coordinates with other parties at the same level and those under the Study Program (laboratories, study centers, lecturers' groups), as well as with stakeholders, practitioners, professionals, users, and alumni. These steps are standard steps set by the Directorate General of the Higher Education in order to produce certified and qualified alumni to meet the needs of the job market.

The IQNF Curriculum Structure of the Public Administration Study Program. The structure of the curriculum is the subjects which in this case refers to the courses that must be taken by students, as this is in accordance with the statement by Firmansyah (2007, p. 140) "the structure of the curriculum is a pattern and arrangement of subjects that must be taken by participants in learning activities." The curriculum structure in the Public Administration Study Program is formulated with Semester Credit System (SKS), for students to take in each lecture activity. Each lecture activity consists of 50 minutes face to face, 60 minutes of structured activity, and 60 minutes of independent study. The study loads taken by the students to graduate is 147 credits divided into 8 semesters consisting of 138 credits of lectures, 3 credits of apprenticeship, and 6 credits of thesis as stated in the form of the Faculty (2014, pp. 45):

"The undergraduate study program load is 147 credits consisting of 47 compulsory subjects (138 credits) and three (3) elective courses (9 credits). Each course offers 9 to 13 elective courses weighting of three (3) credits each as an effort to accommodate students' needs."

The curriculum structure of the Public Administration Study Program is prepared in 2014 based on the level of the materials consisting of subjects in the category of National Compulsory, University Compulsory, Faculty Compulsory, Major Compulsory, Study Program Compulsory, and Elective Courses.

Learning Outcomes (LO) of the IQNF Curriculum. Learning Outcomes (LO) based on the guidebook of Learning Achievement of the Study Program (2014) is a measure on the capabilities of students or alumni obtained after completing the learning process consisting of internalization of knowledge, attitudes, skills, competencies, and accumulated work experience (internship). The determining LO parameters set by the Directorate General of Higher Education consist of attitudes, general skills, special skills, and knowledge. As for the method of measurement of LO applied by the Public Administration Study Program is (1) quiz, (2) group discussion, (3) group work, (4) middle test and final test, and other methods which are prepared by the lecturers themselves. In determining the LO of the course, the Faculty refers to the regulations set by the Directorate General of Higher Education which is then applied by the Department with the Semester Course Design and the curriculum body.

Inhibiting and Supporting Factors of IQNF Curriculum. Theoretically, the supporting factors that influence the success of policy implementation according to Edward III (1980, in Suwarno, 2017) consists of communication factors, resources, dispositions, and bureaucratic structures. One of the communication factors in the implementation of IQNF policy in the Public Administration Program Study Program is done during curriculum preparation such as through Curriculum Workshop in 2014, conducted in cooperation with Indonesian Association for Public Administration (IAPA) team of East Java. The resource factor is the support derived from human resources consisting of educators and employees. The lecturers consist of 34 masters, 29 doctors, and 7 professors. Financial and material resources consisting of facilities and infrastructure such as buildings, reading rooms, laboratories, classrooms (AC, 
sound systems, LED TV or LCD projectors, desks, chairs, white boards, WIFI, etc.) Furthermore, the disposition factor is in the form of rules and commitment from internal stakeholders related to the change of several courses with rational arguments in order to achieve LO as a way to produce qualified graduates. This involves the professors and some competent doctors in the field to criticize the various proposals for subject changes. Factors supporting the structure of bureaucracy can be seen with the support of funding that is autonomously submitted by the Faculty to the Department and the Department hands the financial management over to the Study Program in accordance with the programs submitted to the Department. The other bureaucratic structure is in the form of handover of authority from the Dean to the Department to submit the composition of the review team and the drafter of the curriculum with all its activities.

The inhibiting factor comes from the disposition from lecturers. In the implementation, some lecturers do not write Lecturing Journals in accordance with the Lesson Plans prepared that the department and study program have difficulty to evaluate whether Lesson Plans have been implemented optimally. In addition, some lecturers still have not compiled complete Lesson Plans.

\section{CONCLUSION} drawn:

Based on the findings that has been described above, some conclusions can now be

The Public Administration Study Program of the undergraduate level of the Faculty of Administrative Sciences of the University of Brawijaya has implemented the public policy on IQNF Curriculum in accordance with applicable regulations.

The implementation of IQNF Curriculum only focuses on the creation of qualified graduates.

The Public Administration Study Program has received sufficient support in the form of communication support, resources, and disposition as well as from the bureaucratic structure of the Faculty. Although in fact the support of disposition has not been optimal.

\section{REFERENCES}

1. "Borang Institusi Fakultas IImu Administrasi". 2014. Fakultas IImu Administrasi. Universitas Brawijaya, Indonesia.

2. Firmansyah, F. 2007. Implementasi Kurikulum Tingkat Satuan Pendidikan (Struktur dan Kendalanya). Tadrîs. Volume 2. Nomor 1. 2007. Retrieved on January 20, 2016 from http://ejournal.stainpamekasan.ac.id/index.php/tadris/article/view/207/198

3. Given, L.M. 2008. The Sage encyclopedia of qualitative research methods. SAGE

4. Publications, Inc. United States of America

5. Liedl, C. 2011. Top-down vs. Bottom-up Does a top-down approach bear more advantages than a bottom-up approach within the implementation process of housing security projects?. Unpublished Undergraduate Thesis. Universiteit Twente. Netherlands. Retrieved on May 27, 2017 from http://essay.utwente.nl/61106/1/BSc_B_Liedl.pdf

6. Miller, G.J. \& Mara, S.S 2007. Handbook of Public Policy Analysis, Theory, Politics and Methods. CRC Press. USA

7. Nugroho, R. 2008. Public Policy. Jakarta: PT Elex Media Komputindo.

8. "Panduan Penyusunan Capaian Pembelajaran Lulusan Prigram Studi". 2014. Direktorat Pembelajaran Dan Kemahasiswaan Direktorat Jenderal Pendidikan Tinggi Kementrian Pendidikan Dan Kebudayaan. Retrieved on August 8, 2016 from http://belmawa.ristekdikti.go.id/dev/wpcontent/uploads/2015/11/6APanduanPenyusunanCP.pdf

9. "Panduan Penyusunan Capaian Pembelajaran Program Studi". 2014.. Retrieved on March 15, 2017 dari http://belmawa.ristekdikti.go.id/dev/wp-content/uploads/2015/11/6APanduan-Penyusunan-CP.pdf 
10. Smith, K.B \& Larimer, C.W. 2009. The Public Policy Theory Primer. Westview Press. USA

11. Suwarno. 2017. Implementasi Kebijakan Berbasis Kelembagaan, Komunikasi, Sumber Daya, Disposisi, dan Struktur Birokrasi Dalam Menggerakkan Pelatihan Menuju Prestasi Kerja. Disertasi. Fakultas IImu Administrasi. Universitas Brawijaya

12. Tim IQNF-Direktorat Akademik \& Ditjen Dikti-Depdiknas (n.d). Indonesian Qualification Framwork ppt. Indonesia

13. Yin, R.K. 2011. Qualitative Research from Start to Finish. The Guilford Press. United States of America. 